\title{
Геохимический состав амфиболитов Ингозерского массива
}

\section{Ниткина Е.А., Козлов Н.Е., Козлова Н.Е.}

Геологический институт КНЦ РАН, Anamumbl,nitkina@geoksc.apatity.ru; kozlov@geoksc.apatity.ru

Аннотация. В статье приведены данные по геологическому строению массива и результаты изучения геохимических особенностей Ингозерского массива. Петро- и геохимические характеристики пород Ингозерского массива сходны с породами тоналит-трондьемит-гранодиоритовых комплексов (TTG) известных на других архейских щитах. Полевошпатовый амфиболит характеризуется распределением редкоземельных элементов соответствующим уровню коматиитовых базальтов.

Ключевые слова: геохимия и геология архейских комплексов ТTГ Кольского региона, U-Pb датирвоание.

\section{Geochemical features of the amphibolites of the Ingozero massif}

Nitkina E.A., Kozlov N.E., Kozlova N.E.

GIKSCRAS, Apatity,nitkina@geoksc.apatity.ru; kozlov@geoksc.apatity.ru

Abstract. The article presents the geological data and the results of a geochemical and geochronological study of the Ingozero massif. The petro- and geochemical characteristics of the rocks of the Ingozero massif are similar to the rocks of the tonalite-trondjemite-granodiorite complexes (TTG) known on other Archean Shields. Feldspar amphibolite is characterized by the of rare-earth elements distribution corresponding to the level of basaltic komatiite.

Key words: geochemistry and geology of the Archaean TTG of Kola Region; isotope U-Pb dating.

Ингозерский массив расположен в северной части Беломорского мобильного пояса на СВ Балтийского щита (рис. 1) (Балаганский, 2002) и представляет собой комплекс ТТG (Объяснительная записка..., 1994; Геологическая карта..., 1996; Vetrin et al., 2018). Ингозерский массив (рис. 1) сложен биотитовыми, биотит-амфиболовыми, амфибол-биотитовыми гнейсами, амфиболитами, гранитами, гранодиоритами и пегматитами (Козлов и др., 2006; Батиева, Бельков, 1968).

Цель данной работы - определить геохимические особенности амфиболитов, входящих в состав Ингозерского массива, и по имеющимся данным по геохимии пород массива установить источники формирования пород Ингозерского массива.

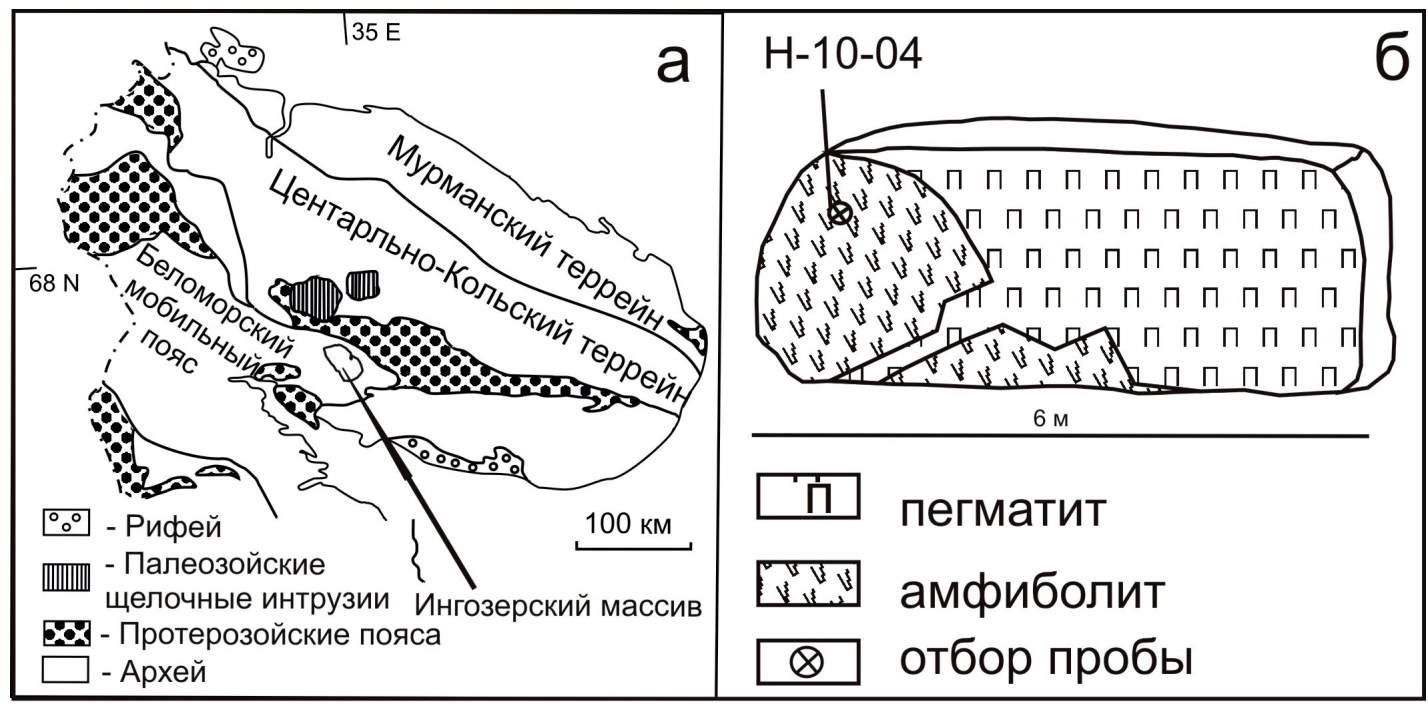

Рис. 1. а - Схематическая карта Кольского полуострова (Балаганский, 2002) с изменениями авторов; б - схема геологического строения «участка 4» с отбором проб.

Fig. 1. a - Geological scheme of the Kola Peninsula (Balaganskiy, 2002) with the authors' changes; $\sigma$ - geological scheme of the "Exposure 4" with sampling point. 


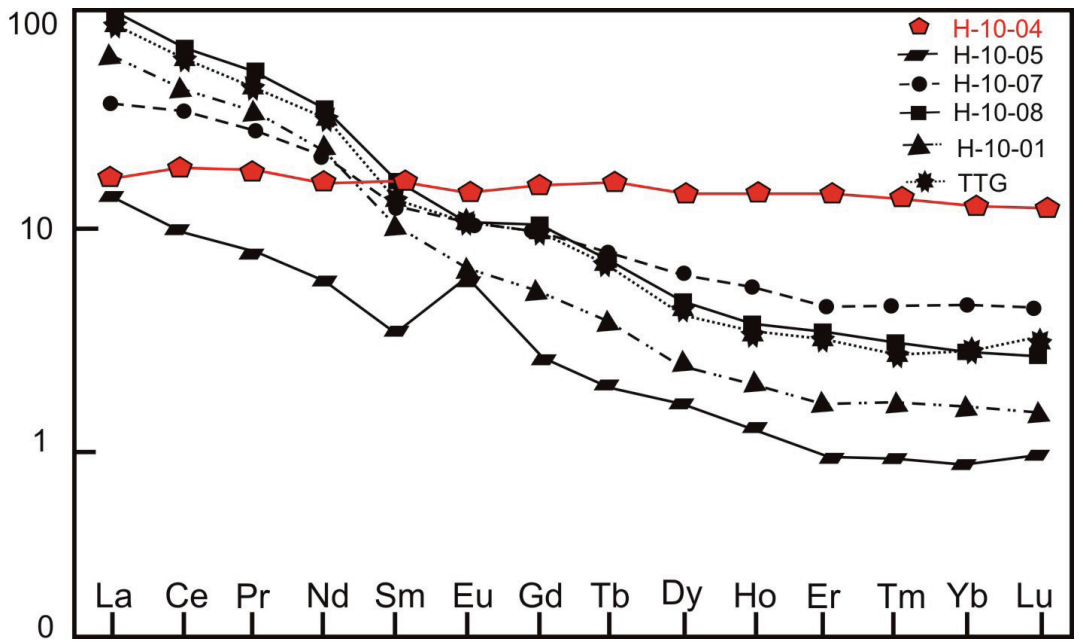

Рис. 2. Распределение РЗЭ, нормированное к хондриту (О’Connor, 1965).

Fig. 2. Chondrite normalized REE patterns (O’Connor, 1965) for the Ingozero massif rocks.
Последовательность эндогенных процессов Ингозерского массива (Козлов и др., 2006) включает следующие этапы: (1) формирование исходных пород для гнейсов; (2) внедрение даек основных пород; (3) деформация и рассланцевание пород; (4) внедрение гранитных тел и микроклинизация биотитовых гнейсов; (5) образование тел пегматита; (6) образование пегматитовых и гранитных жил и (7) образование кварцевых жил. Проба амфиболитов на геохимические исследования была отобрана из амфиболитов

(H-10-04) на участке 4, ранее описаны пробы (Ниткина, Баянова, 2018; Nitkina et al., 2019) из биотитамфиболовых гнейсов (Н-10-06) и плагиогранитов (Н-10-05) на участке 8, из амфибол-биотитовых гнейсов (Н-10-07) на участке 9, из биотит-амфиболовых гнейсов (Н-0-08), пегматитов (Н-10-10) и жильного гранита (N-10-09) на участке 10.

Возрасты этапов деформаций пород: формирование протолита гнейсов $-3149 \pm 46$ млн. лет (Bayanova et al., 2016); возраста процессов метаморфизма (Ниткина, Баянова, 2018; Nitkina et al., $2019)-2697 \pm 9$ млн. лет для биотитового гнейса, $2725 \pm 2$ млн. лет и $2667 \pm 7$ млн. лет для амфиболбиотитового гнейса; $2727 \pm 5$ млн. лет и $2615 \pm 8$ млн. лет для биотит-амфиболового гнейса; возрасты внедрения гранитоидов составляют $2549 \pm 31$ млн. лет для пегматита, $2208 \pm 17$ млн. лет для плагиогранитов и $1644 \pm 7$ млн. лет для гранитных жил.

Отсутствие европиевой аномалии и высокие содержания легких редкоземельных элементов для различных гнейсов (рис. 2) свидетельствует о происхождении пород из обогащенного источника без значительной роли фракционной кристаллизации (Ниткина, Баянова, 2018; Nitkina et al., 2019). Само распределение редкоземельных элементов исследуемых пород сходно с распределением таковых в породах комплексов ТТГ, известных на других докембрийских щитах Мира (Moyen\&Martin, 2012). Проба плагиогранита характеризуется высоким содержанием К и низким Са, уменьшением содержаний от лёгких до тяжелых элементов и положительной европиевой аномалией. Полевошпатовый амфиболит характеризуется распределением редкоземельных элементов по (Конди, 1983) соответствующим уровню коматиитовых базальтов.

Таблица 1. Химический состав амфиболитов Ингозерского массива.

Table 1. Chemical composition of the amphibolites of the Ingozero massif rocks.

\begin{tabular}{|c|c|c|c|c|c|c|c|c|c|c|c|c|c|}
\hline $\mathrm{SiO}_{2}$ & $\mathrm{TiO}_{2}$ & $\mathrm{Al}_{2} \mathrm{O}_{3}$ & $\mathrm{Fe}_{2} \mathrm{O}_{3}$ & $\mathrm{FeO}$ & $\mathrm{MnO}$ & $\mathrm{MgO}$ & $\mathrm{CaO}$ & $\mathrm{Na}_{2} \mathrm{O}$ & $\mathrm{K}_{2} \mathrm{O}$ & & & & \\
\hline 49.14 & 1.24 & 13.96 & 3.70 & 10.85 & 0.23 & 6.25 & 8.91 & 2.97 & 0.63 & & & & \\
\hline $\mathrm{La}$ & $\mathrm{Ce}$ & $\mathrm{Pr}$ & $\mathrm{Nd}$ & $\mathrm{Sm}$ & $\mathrm{Eu}$ & $\mathrm{Gd}$ & $\mathrm{Tb}$ & Dy & Ho & $\mathrm{Er}$ & $\mathrm{Tm}$ & $\mathrm{Yb}$ & $\mathrm{Lu}$ \\
\hline 4.9 & 14.4 & 2.1 & 9.3 & 3.1 & 1.01 & 3.8 & 0.73 & 4.4 & 0.98 & 2.9 & 0.43 & 2.5 & 0.37 \\
\hline
\end{tabular}

Породы Ингозерского массива имеют схожие характеристики петрохимического и геохимического состава с породами тоналит-трондъемит-гранодиоритовых (ТТГ) комплексов, установленных на других докембрийских щитах Мира. Полевошпатовый амфиболит по содержанию РЗЭ соотносится с коматиитовыми базальтами и соответствует тренду эволюции массива.

Работа выполнена в рамках темы НИР № 0226-2019-0052. 


\section{Литература}

1. Балаганский В.В. Главные этапы тектонического развития северо-востока Балтийского щита в палеопротерозое. Автореф. дисс. ... докт. геол.-мин. наук. СПб. Наука. 2002. 32 С.

2. Батиева И.Д., Бельков И.В. Гранитоидные формации Кольского полуострова // Очерки по петрологии, минералогии и металлогении гранитов Кольского полуострова. Л. Изд-во: Наука. 1968. С. $28-43$.

3. Геологическая карта Кольского региона (северо-восточная часть Балтийского щита) масштаба 1:500000. (Гл. ред. Ф.П. Митроофанов. Авторы: Балаганский В.В., Басалаев А.А., Беляев О.А., Пожиленко В.И., Радченко А.Т., Радченко М.К.). Апатиты. 1996.

4. Козлов Н.Е., Сорохтин Н.О., Глазнев В.Н., Козлова Н.Е., Иванов А.А., Кудряшов Н.М., Мартынов Е.В., Тюремнов В.А., Матюшкин А.В., Осипенко Л.Г. Геология архея Балтийского щита. СПб. Изд-во: Наука. 2006. 345 с.

5. Конди К. Архейские зеленокаменные пояса. М. Изд-во: Мир. 1983. 390 с.

6. Мыскова Т.А., Бережная Н.Г., Глебовицкий В.А., Милькевич Р.И., Лепехина Е.Н., Матуков Д.И., Антонов А.В., Сергеев С.А., Шулешко И.К. Находки древнейших цирконов с возрастом 3600 млн. лет в гнейсах кольской серии Центрально-Кольского блока Балтийского щита (U-Pb, SHRIMP-II) // Докл. РАН. 2005. Т. 402. № 1. С. 82-86.

7. Ниткина Е.А., Баянова Т.Б. Изотопно-гохронологическое изучение Ингозерсого массива (Кольский полусотров). Вестник МГТУ. 2018. 21. С. 51-60.

8. Объяснительная записка к геологической карте северо-восточной части Балтийского щита, масштаба 1:500 000. (Радченко А.Т., Балаганский В.В., Басалаев А.А., Беляев О.А., Пожиленко В.И., Радченко М.К.). Препринт. Апатиты. Изд-во: КНЦ РАН. 1994. 95 с.

9. Bayanova T.B.; Kunakkuzin E.L.; Serov P.A.; Fedotov D.A.; Borisenko E.S.; Elizarov D.V.; Larionov A.V. Precise U-Pb (ID-TIMS) and SHRIMP-II ages on single zircon and Nd-Sr signatures from Achaean TTG and high aluminum gneisses on the Fennoscandian Shield. In Proceedings of the 32nd Nordic Geological Winter Meeting; Helsinki. Finland. 13-15 January 2016. P. 172-174.

10. Moyen J.-F.; Martin H. Forty years of TTG research. Lithos 2012. 148. P. 312-336.

11. Nitkina E.A, Kozlov N.E., Kozlova N.E., Kaulina T.V. Geochemical Features and Geological Processes Timescale of the Achaean TTG Complexes of the Ingozero Massif and the Pechenga Frame (NE Baltic Shield) // Minerals. 2019. 9. 767; doi:10.3390/min9120767.

12. O’Connor, J.T. A classification for quartz-rich igneous rocks based on feldspar ratios. Geol. Surv. Prof. Pap. 1965. 527. 79.

13. Vetrin V.R.; Belousova E.A.; Kremenetsky A.A. Lu-Hf Isotopic Systematics of Zircon from Lower Crustal Xenoliths in the Belomorian Mobile Belt. Geol. Ore Depos. 2018. 60. P. 568-577. 